International Journal of Engineering \& Technology, $7(2.29)(2018) 849-852$
International Journal of Engineering \& Technology
SPC
Website: www.sciencepubco.com/index.php/IJET
Research paper

\title{
Sediment Transport and Characteristics in Perak River and Kurau River
}

\author{
A. Saleh", I. Abustan*, Mohd Remy Rozainy M. A. Z. , N. Sabtu \\ School of Civil Engineering, Engineering Campus, Universiti Sains Malaysia, 14300 Nibong Tebal, Penang, Malaysia. \\ *Corresponding Author E-Mail: Ceismail@Usm.My
}

\begin{abstract}
Particle size is the most important parameter to deal in sediment transport processes. This parameter is important to determine the class of sediment transport in river. It is also important for the selection of site for sand mining operation through the determination of the size of sediment, sediment capacity and sediment replenishment rate. Data were obtained through observations made from two rivers namely Sungai Perak and Sungai Kurau in Malaysia. The rivers were categorized as wide river for Sungai Perak and small river for Sungai Kurau. For Sungai Perak, the width of river ranges from 248.18 to 338.53 meter whilst the width of Sungai Kurau ranges from 9 to 11 meter. Data covers flow discharges from $130.988 \mathrm{~m}^{3} / \mathrm{s}$ to $435.915 \mathrm{~m}^{3} / \mathrm{s}$ for Sungai Perak and from $2.52 \mathrm{~m}^{3} / \mathrm{s}$ to $4.723 \mathrm{~m}^{3} / \mathrm{s}$ for Sungai Kurau. Based on the results, the bed load of two rivers are found to be mostly uniform mixture. The results indicate that these two Malaysian rivers mostly have uniform bed load The bed material for the two rivers are poorly graded mixture and the median size of bed loads mostly ranges from 0.62 to $2.94 \mathrm{~mm}$.
\end{abstract}

Keywords: Sediment Transport; Non-cohesive sediment; Sediment Distribution

\section{Introduction}

River sediment consists of a mixture of particles of various sizes[1]. [1] added that the size distribution of a sediment mixture can be determined using the sieve analysis. The sediment size distribution is an important parameter to determine the sediment load of any particular river. The sediment size distribution is differs depending on many factors such as river discharge and river geology. This information is essential especially for design purposes such as design stable channel, hydraulic structural and water intake. Suspended loads are mostly clay and silt whereas sand and gravel are common bed loads. The data collection of these rivers could be used to estimate the suitability of available sand material and the flux of sediment transport locally.

The mixture of bed material can influence the sediment load calculations[2]. For example, [3] studied on sediment characteristic in Malaysia rivers to develop the total sediment load equation for Malaysia river. Based on the [3] observation, sediment in Malaysia rivers have a uniformity coefficient $[\mathrm{Cu}]$ ranging from 1.053 to 5.0 [average $\mathrm{Cu}=3.153$ ]. It shows that Malaysia rivers sediment particles are nearly uniform.

According to [4], the non-uniformity of bed load or bed material can cause selective transport processes or grain sorting. [4] described that this grain sorting can related to the some movement of sediment particles in a mixture near incipient motion at low bedshear stresses and when generalized transport at higher shear stresses. It is also essential to determine the size of median sediment, uniformity coefficient, gradation coefficients and specific gravity to evaluate the river sediment. [5] define the particle-size distribution, uniformity coefficient and gradation coefficient as follow:

\section{a. Particle-size distribution.}

The sediment size $\mathrm{d}_{50}$ for which $50 \%$ weight of the material is finer is called the median size. Meanwhile, for $\mathrm{d}_{60}$ and $\mathrm{d}_{10}$ are values of grain size for which $60 \%$ and $10 \%$ of the material are finer, respectively. Usually, the size of sediment of $d_{50}$ is use to in mostly sediment transport equations.

\section{b. Uniformity Coefficient [Cu]}

The uniformity of the sediment size was tested using the uniformity coefficient $[\mathrm{Cu}]$ equation given in equation 1 . When $\mathrm{Cu}$ value is less than 3 , the sediment sample is uniformly distributed[3].

$$
\mathrm{Cu}=\frac{\mathrm{d}_{60}}{\mathrm{~d}_{10}}
$$

\section{c. Gradation Coefficients [ $\sigma \mathrm{g}]$}

Gradation of sediment mixture is a measurement of non-uniformity of sediment mixtures. If $\sigma \mathrm{g}<1.4$, the sediment is uniform; when the $\sigma g>1.4$ the sediment is non-uniform[1]. The formula of gradation coefficient as shown in equation 2 ;

$$
\sigma_{g}=\sqrt{\frac{d_{84}}{d_{16}}}
$$




\section{Methodology}

\subsection{Study Area}

Two rivers or 'Sungai' as they are called in Malay were selected in order to study optimal sand removal capacity which have different characteristic in river morphology and different level of sand mining activities. The first river is Sungai Perak which is located in Kampung Pendiat, Bota, Perak. Sungai Perak faced major flooding on December 2014[6]. Five cross sections were selected at Pendiat, Perak. This river not only provides water sources for local people, it is also used for recreational, fishery, mining, and irrigation of paddy fields. The second river is Sungai Kurau. Sungai Kurau is located at Batu Kurau, Perak. Sungai Kurau can be classified as a small river. The width of Sungai Kurau is in the range of 9 to 10 meters. For Sungai Kurau, four cross sections were selected to analyze sediment load and sediment characteristic in this river. Both rivers are located in Perak state.

\subsection{Sediment Sampling}

In this study, sediment samples were collected using a Helley-Smith sediment sampler for bed load sampling. For suspended load, the samples were collected manually using a bottle. Van Veen grabber was used to obtain bed material. The sediment sampling method used is adopted from the Guidelines for Field Data Collection and Analysis of River Sediment by [7].

\section{a.Bed load Sampler}

The Helley-Smith bed load samplers are suitable for sampling sand, silt, and gravel [8]. Usually, the difference of this sampler is sampling type whether it is cable or hand held sampling $[7,9,10]$.

\section{b.Suspended load Sampler}

For suspended sediment sampling, bottling sample was used to collect the suspended sediment in river. Bottling sample is the simplest method to measure the suspended load. The result of this method is still acceptable which noted by $[9,11]$. [11] suggested that bottle sampling method is taken isokinetically by submerging container in streamflow. This method is time-tested, allows determination of concentration and size distribution, and economic.

\section{c.Bed material Sampler}

The Van-Veen grabber is a lightweight sampler designed to take large samples in soft bottoms. The long lever arms and the sharp cutting edges on the bottom of the scoops, enable it to cut deeply into the softer bottoms[12].

\subsection{Sediment Analysis}

Sediment analysis was carried out after the sediment loads were obtained from rivers. Three analysis were conducted which are: sieve analysis [particle size distribution] for bed material and bed load, filtration method for suspended load and specific gravity for bed material and sediment load.

\section{Results and Discussions}

\subsection{River Profile}

\section{a. Sungai Perak}

Five cross sections were selected to obtain sediment data and river profile. The width of Sungai Perak ranges from $248.18 \mathrm{~m}$ to 338.53 $\mathrm{m}$ across. The sediment collections and cross section measurements were carried out on 15 June 2015 and 19 October 2015. The average depth of this river when the depth measured on 15 June 2015 is $1.706 \mathrm{~m}$ and $1.572 \mathrm{~m}$ when take measurement on 19 October 2015.

Table1: Sungai Perak profile and sediment load.

\begin{tabular}{|c|c|c|c|c|c|}
\hline Data & $\begin{array}{c}\text { Depth } \\
{[\mathbf{m}]}\end{array}$ & $\begin{array}{c}\text { Width } \\
{[\mathbf{m}]}\end{array}$ & $\begin{array}{c}\text { Aver- } \\
\text { age } \\
\text { Veloc- } \\
\text { ity } \\
{[\mathbf{m} / \mathbf{s}]}\end{array}$ & $\begin{array}{c}\text { Average } \\
\text { Dis- } \\
\text { charge } \\
{\left[\mathbf{m}^{\mathbf{3} / \mathbf{s}}\right]}\end{array}$ & $\begin{array}{c}\text { Total } \\
\text { sedi- } \\
\text { ment } \\
\text { load } \\
{[\mathbf{k g} / \mathbf{s}]}\end{array}$ \\
\hline SPRK1/07/15 & 1.589 & 299.49 & 0.906 & 405.731 & 21.072 \\
\hline SPRK2/07/15 & 1.433 & 328.8 & 0.968 & 389.107 & 30.939 \\
\hline SPRK3a/07/15 & 1.719 & 142.73 & 0.956 & 226.767 & 20.487 \\
\hline SPRK3b/07/15 & 1.85 & 140.42 & 0.940 & 230.209 & 20.487 \\
\hline SPRK4/07/15 & 1.754 & 326.58 & 0.9498 & 388.962 & 29.553 \\
\hline SPRK5/07/15 & 1.895 & 248.18 & 0.894 & 424.065 & 61.681 \\
\hline SPRK1/10/15 & 1.894 & 274.36 & 0.893 & 410.907 & 53.537 \\
\hline SPRK2/10/15 & 1.328 & 312.51 & 0.9 & 429.364 & 88.790 \\
\hline SPRK3a/10/15 & 2.003 & 156.09 & 0.946 & 283.379 & 22.636 \\
\hline SPRK3b/10/15 & 1.17 & 125.78 & 0.877 & 130.988 & 17.025 \\
\hline SPRK4/10/15 & 1.339 & 338.53 & 0.891 & 435.915 & 80.273 \\
\hline SPRK5/10/15 & 1.696 & 252.06 & 0.948 & 398.746 & 47.912 \\
\hline
\end{tabular}

The average velocities were between $0.877 \mathrm{~m} / \mathrm{s}$ to $0.968 \mathrm{~m} / \mathrm{s}$ respectively. Sungai Perak profile cross sections were observed by using Acoustic Doppler Current Profiler [ADCP]. The sediment load of Sungai Perak is slightly high which ranges from $17.025 \mathrm{~kg} / \mathrm{s}$ to $80.273 \mathrm{~kg} / \mathrm{s}$. Specific gravity of sediment for Sungai Perak is 2.640 . The detailed results of river profiles data are as shown in Table 1.

\section{b. Sungai Kurau Profile}

The river profile of Sungai Kurau was measured by using Global Water Flow Probe on August 2015 and September 2015. The detailed results of Sungai Kurau's profiles are as shown in the Table 2. The average velocity of Sungai Kurau ranges from $0.45 \mathrm{~m} / \mathrm{s}$ to $0.636 \mathrm{~m} / \mathrm{s}$. The highest sediment load of Sungai Kurau is $0.878 \mathrm{~kg} / \mathrm{s}$ which was observed at Line 2 on August 2015.

For second measurement on September 2015, the highest sediment load was $0.690 \mathrm{~kg} / \mathrm{s}$ at Line 4 . Meanwhile, the lowest sediment load was $0.350 \mathrm{~kg} / \mathrm{s}$ [Line 3 on August 2015] and $0.222 \mathrm{~kg} / \mathrm{s}$ [Line 2 on September 2015]. From SKRU2/08/15 data, it shows the highest average velocity is $0.636 \mathrm{~m} / \mathrm{s}$ with the highest sediment load of $0.878 \mathrm{~kg} / \mathrm{s}$. Specific gravity of sediment for Sungai Kurau is 2.610 .

Table2: Sungai Kurau profile and sediment load.
\begin{tabular}{|c|c|c|c|c|c|}
\hline \multirow{2}{*}{ Data } & $\begin{array}{c}\text { Depth } \\
{[\mathbf{m}]}\end{array}$ & $\begin{array}{c}\text { Width } \\
{[\mathbf{m}]}\end{array}$ & $\begin{array}{c}\text { Aver- } \\
\text { age } \\
\text { Veloc- } \\
\text { ity } \\
{[\mathbf{m} / \mathbf{s}]}\end{array}$ & $\begin{array}{c}\text { Average } \\
\text { Dis- } \\
\text { charge } \\
{\left[\mathbf{m}^{3} / \mathbf{s}\right]}\end{array}$ & $\begin{array}{c}\text { Total } \\
\text { sedi- } \\
\text { ment } \\
\text { load } \\
{[\mathbf{k g} / \mathbf{s}]}\end{array}$ \\
\hline SKRU1/08/15 & 0.722 & 11 & 0.509 & 4.420 & 0.743 \\
\hline SKRU2/08/15 & 0.623 & 11 & 0.636 & 4.723 & 0.878 \\
\hline SKRU3/08/15 & 0.653 & 10.2 & 0.491 & 3.492 & 0.350 \\
\hline SKRU4/08/15 & 0.616 & 11 & 0.564 & 4.062 & 0.803 \\
\hline SKRU1/09/15 & 0.504 & 11 & 0.591 & 3.544 & 0.487 \\
\hline SKRU2/09/15 & 0.543 & 9 & 0.45 & 2.52 & 0.222 \\
\hline SKRU3/09/15 & 0.539 & 11 & 0.527 & 3.242 & 0.337 \\
\hline SKRU4/09/15 & 0.507 & 11 & 0.509 & 2.976 & 0.690 \\
\hline
\end{tabular}

\subsection{Sungai Perak Sediment Size Distributions}

The size range was between $0.62 \mathrm{~mm}$ to $1.19 \mathrm{~mm}$ can be categorized as fine sand for the bed load size of Sungai Perak. Typical Scurve of bed load obtained from Sungai Perak are as shown in Figure 1 . The uniformity of sediments was between 2.50 to 4.24 . The the gradation coefficients ranges from 1.49 to 2.84. Based on Table 3 Error! Reference source not found., the average of median size is 0.93 which can be categorized as coarse sand range. The uniformity of bed load was 3.09 which slightly fit into uniform range. However, the gradation of material for this river was quite high which can classed as poorly graded sand.

The uniformity of bed load slightly increase based on the two times data observation in Sungai Perak. The uniformity decrease at Line 1 [SPRK1/10/15] and this shows that the coarse sediment is higher 
than fine sediment based on October data collection compared to July data collection. The sediment of Sungai Perak can be categorized as slightly uniform. The detailed results of bed load size distributions are shown in Table 3.

The ranges of bed material size were in the range of $0.78 \mathrm{~mm}$ to $2.94 \mathrm{~mm}$ can be categorized as coarse sand and slightly fine gravel respectively. Average of median size $1.349 \mathrm{~mm}$ of Sg perak which fit into very coarse sand. Typical S-curve of bed material obtained from Sungai Perak is as shown in Figure 2. The uniformity of sediments ranges from 1.86 to 5.60. The gradation coefficients were between 1.13 and 2.84 . The average of uniformity and gradation were 3.42 and 2.06 respectively.

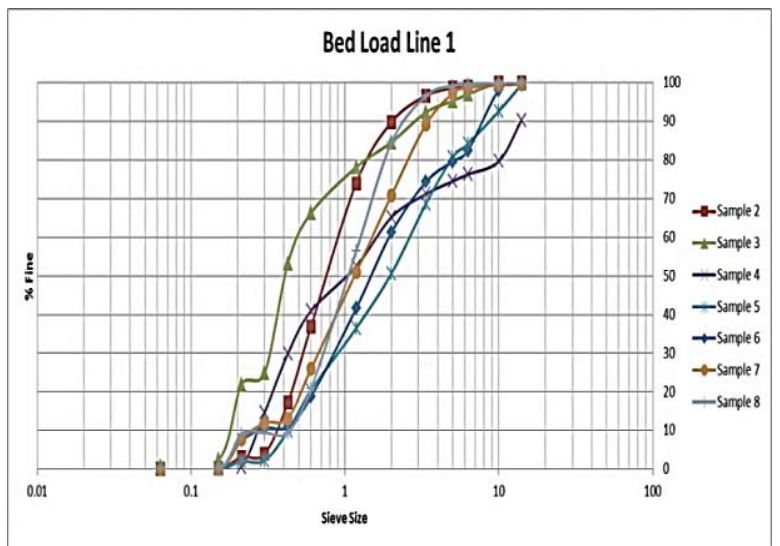

Fig. 1: S-curve of bed load obtained from Sungai Perak

Table 3: Bed load size distributions of Sungai Perak

\begin{tabular}{|c|c|c|c|c|c|c|c|c|c|c|c|}
\hline Sample No & $d_{10}$ & $\mathrm{~d}_{16}$ & $d_{35}$ & $d_{50}$ & $d_{60}$ & $d_{65}$ & $\mathbf{d}_{75}$ & $d_{84}$ & $d_{90}$ & $d_{60} / d_{10}$ & {$\left[d_{84} / d_{16}\right]^{0.5}$} \\
\hline SPRK1/07/15 & 0.28 & 0.37 & 0.65 & 1.00 & 1.33 & 1.53 & 2.43 & 4.14 & 5.24 & 4.24 & 2.84 \\
\hline SPRK2/07/15 & 0.20 & 0.26 & 0.44 & 0.62 & 0.77 & 0.85 & 1.12 & 1.49 & 2.35 & 2.50 & 1.49 \\
\hline SPRK3/07/15 & 0.19 & 0.26 & 0.46 & 0.66 & 0.82 & 0.93 & 1.16 & 1.56 & 1.91 & 2.85 & 1.59 \\
\hline SPRK4/07/15 & 0.29 & 0.34 & 0.57 & 0.77 & 0.93 & 1.04 & 1.30 & 1.69 & 2.30 & 2.64 & 1.67 \\
\hline SPRK5/07/15 & 0.38 & 0.48 & 0.76 & 1.04 & 1.32 & 1.51 & 2.27 & 3.11 & 3.89 & 3.22 & 2.10 \\
\hline SPRK1/10/15 & 0.41 & 0.49 & 0.80 & 1.05 & 1.32 & 1.46 & 1.80 & 2.41 & 3.02 & 3.55 & 2.37 \\
\hline SPRK2/10/15 & 0.49 & 0.60 & 0.90 & 1.16 & 1.39 & 1.51 & 1.81 & 2.24 & 2.74 & 2.50 & 1.69 \\
\hline SPRK3/10/15 & 0.34 & 0.40 & 0.64 & 0.90 & 1.13 & 1.20 & 1.69 & 2.35 & 2.97 & 2.52 & 1.72 \\
\hline SPRK4/10/15 & 0.36 & 0.43 & 0.66 & 0.91 & 1.10 & 1.22 & 1.54 & 1.85 & 2.32 & 3.35 & 1.88 \\
\hline SPRK5/10/15 & 0.46 & 0.55 & 0.84 & 1.19 & 1.56 & 1.83 & 2.32 & 3.10 & 3.79 & 3.53 & 2.32 \\
\hline
\end{tabular}

Table 4: Bed material size distributions of Sungai Perak

\begin{tabular}{|c|c|c|c|c|c|c|c|c|c|c|c|}
\hline Sample No & $\mathbf{d}_{\mathbf{1 0}}$ & $\mathbf{d}_{\mathbf{1 6}}$ & $\mathbf{d}_{\mathbf{3 5}}$ & $\mathbf{d}_{\mathbf{5 0}}$ & $\mathbf{d}_{\mathbf{6 0}}$ & $\mathbf{d}_{\mathbf{6 5}}$ & $\mathbf{d}_{\mathbf{7 5}}$ & $\mathbf{d}_{\mathbf{8 4}}$ & $\mathbf{d}_{\mathbf{9 0}}$ & $\mathbf{d}_{\mathbf{6} \mathbf{0}} / \mathbf{d}_{\mathbf{1 0}}$ & $\mathbf{[ d}_{\mathbf{8 4}} / \mathbf{d}_{\mathbf{1 6}} \mathbf{]}^{\mathbf{0 . 5}}$ \\
\hline SPRK1/07/15 & 0.59 & 0.75 & 1.17 & 1.58 & 1.92 & 2.12 & 2.81 & 3.66 & 5.07 & 2.97 & 2.00 \\
\hline SPRK2/07/15 & 0.52 & 0.64 & 1.03 & 1.49 & 2.17 & 2.56 & 3.41 & 4.10 & 4.81 & 3.99 & 2.23 \\
\hline SPRK3/07/15 & 0.43 & 0.58 & 0.87 & 1.16 & 1.37 & 1.51 & 1.86 & 2.37 & 3.14 & 3.76 & 1.99 \\
\hline SPRK4/07/15 & 0.34 & 0.39 & 0.60 & 0.78 & 0.98 & 1.09 & 1.38 & 1.85 & 2.60 & 2.23 & 1.62 \\
\hline SPRK5/07/15 & 0.22 & 0.28 & 0.48 & 0.67 & 0.82 & 0.90 & 1.13 & 1.42 & 1.85 & 1.86 & 1.13 \\
\hline SPRK1/10/15 & 0.28 & 0.37 & 0.65 & 1.00 & 1.33 & 1.53 & 2.43 & 4.14 & 5.24 & 4.24 & 2.84 \\
\hline SPRK2/10/15 & 0.49 & 0.69 & 1.22 & 2.94 & 3.94 & 4.41 & 5.99 & 7.34 & 8.45 & 5.60 & 2.67 \\
\hline SPRK3/10/15 & 0.57 & 0.61 & 0.99 & 1.38 & 1.78 & 2.05 & 2.79 & 3.50 & 4.19 & 3.66 & 2.28 \\
\hline SPRK4/10/15 & 0.49 & 0.60 & 1.07 & 1.70 & 2.07 & 2.28 & 2.73 & 3.38 & 4.00 & 3.73 & 2.22 \\
\hline SPRK5/10/15 & 0.37 & 0.43 & 0.62 & 0.79 & 0.94 & 1.03 & 1.26 & 1.60 & 1.99 & 2.11 & 1.64 \\
\hline
\end{tabular}

Table 5: Bed load size distributions of Sungai Kurau

\begin{tabular}{|c|c|c|c|c|c|c|c|c|c|c|c|}
\hline Sample No. & $\mathbf{d}_{\mathbf{1 0}}$ & $\mathbf{d}_{\mathbf{1 6}}$ & $\mathbf{d}_{\mathbf{3 5}}$ & $\mathbf{d}_{\mathbf{5 0}}$ & $\mathbf{d}_{\mathbf{6 0}}$ & $\mathbf{d}_{\mathbf{6 5}}$ & $\mathbf{d}_{\mathbf{7 5}}$ & $\mathbf{d}_{\mathbf{8 4}}$ & $\mathbf{d}_{\mathbf{9 0}}$ & $\mathbf{d}_{\mathbf{6 0}} / \mathbf{d}_{\mathbf{1 0}}$ & ${\left[\mathbf{d}_{\mathbf{8}} / \mathbf{d}_{\mathbf{1 6}} \mathbf{0}^{\mathbf{0 . 5}}\right.}^{\mathbf{2}}$ \\
\hline SKRU1/08/15 & 0.22 & 0.27 & 0.49 & 0.72 & 0.89 & 1.01 & 1.29 & 1.70 & 2.32 & 2.57 & 1.46 \\
\hline SKRU2/08/15 & 0.57 & 0.67 & 0.99 & 1.27 & 1.49 & 1.64 & 2.02 & 2.55 & 3.17 & 2.64 & \\
\hline SKRU3/08/15 & 0.50 & 0.60 & 0.87 & 1.15 & 1.38 & 1.51 & 1.91 & 2.49 & 3.47 & 2.91 & 2.06 \\
\hline SKRU4/08/15 & 0.44 & 0.53 & 0.81 & 1.04 & 1.24 & 1.37 & 1.68 & 2.10 & 2.63 & 2.39 & 1.70 \\
\hline SKRU1/09/15 & 0.47 & 0.58 & 0.87 & 1.12 & 1.35 & 1.49 & 1.81 & 2.28 & 2.90 & 2.87 & \\
\hline SKRU2/09/15 & 0.39 & 0.46 & 0.63 & 0.87 & 1.04 & 1.14 & 1.39 & 1.70 & 2.04 & 2.27 & 1.68 \\
\hline SKRU3/09/15 & 0.42 & 0.50 & 0.78 & 1.11 & 1.38 & 1.57 & 2.02 & 2.62 & 3.28 & 3.42 & 2.32 \\
\hline SKRU4/09/15 & 0.47 & 0.56 & 0.84 & 1.09 & 1.31 & 1.44 & 1.78 & 2.20 & 1.93 & 2.97 & 2.00 \\
\hline
\end{tabular}

Table 6: Bed material size distributions of Sungai Kurau

\begin{tabular}{|c|c|c|c|c|c|c|c|c|c|c|c|}
\hline Sample No & $\mathbf{d}_{\mathbf{1 0}}$ & $\mathbf{d}_{\mathbf{1 6}}$ & $\mathbf{d}_{\mathbf{3 5}}$ & $\mathbf{d}_{\mathbf{5 0}}$ & $\mathbf{d}_{\mathbf{6 0}}$ & $\mathbf{d}_{\mathbf{6 5}}$ & $\mathbf{d}_{\mathbf{7 5}}$ & $\mathbf{d}_{\mathbf{8 4}}$ & $\mathbf{d}_{\mathbf{9 0}}$ & $\mathbf{d}_{\mathbf{6 0}} / \mathbf{d}_{\mathbf{1 0}}$ & ${\left[\mathbf{d}_{\mathbf{8}} / \mathbf{d}_{\mathbf{1 6}} \mathbf{0}^{\mathbf{0 . 5}}\right.}$ \\
\hline SKRU1/08/15 & 0.42 & 0.53 & 0.85 & 1.18 & 1.46 & 1.65 & 2.16 & 2.93 & 4.02 & 3.02 & 2.02 \\
\hline SKRU2/08/15 & 0.61 & 0.74 & 1.19 & 1.64 & 2.00 & 2.20 & 2.75 & 3.35 & 4.35 & 3.36 & 2.11 \\
\hline SKRU3/08/15 & 0.46 & 0.55 & 0.82 & 1.09 & 1.29 & 1.44 & 1.80 & 2.26 & 3.02 & 2.40 & 1.70 \\
\hline SKRU4/08/15 & 0.59 & 0.71 & 1.10 & 1.47 & 1.79 & 1.99 & 2.49 & 3.19 & 4.06 & 3.06 & 2.12 \\
\hline SKRU1/09/15 & 0.53 & 0.65 & 1.07 & 1.51 & 1.86 & 2.06 & 2.65 & 3.49 & 4.32 & 3.58 & \\
\hline SKRU2/09/15 & 0.52 & 0.69 & 1.32 & 1.90 & 2.40 & 2.72 & 3.59 & 4.75 & 5.79 & 4.66 & 2.46 \\
\hline SKRU3/09/15 & 0.40 & 0.48 & 0.77 & 1.08 & 1.32 & 1.45 & 1.90 & 2.35 & 3.02 & 2.86 & 1.88 \\
\hline SKRU4/09/15 & 0.49 & 0.60 & 0.97 & 1.32 & 1.61 & 1.81 & 2.37 & 3.14 & 4.12 & 3.32 & 2.25 \\
\hline
\end{tabular}

This average indicates that the bed material is nearly uniform and poorly graded coarse sand. Based on data sample obtained on July 2015 and October 2015 in Table 4, the uniformity of sediment was slightly increased. Its shows that the high particle of fine sediment is occur in that sediment. The detailed results of bed material size distributions of Sungai Perak as shown in Table 4. 


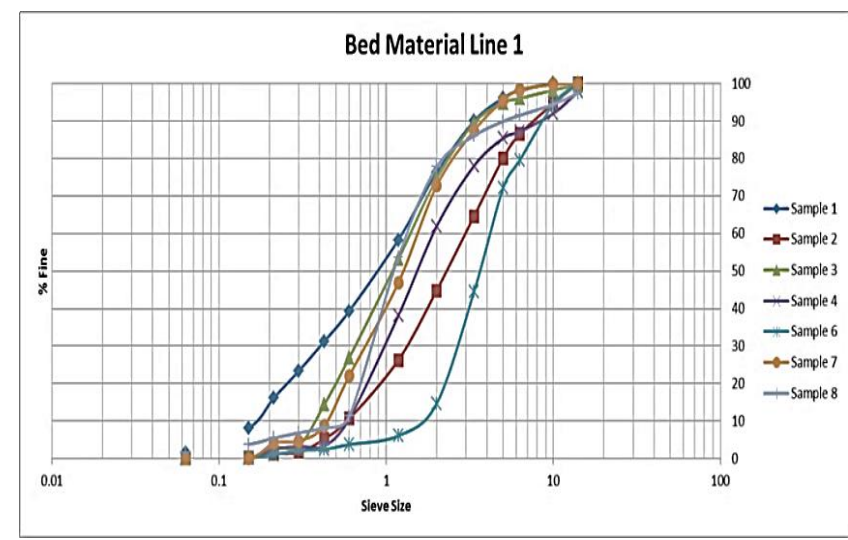

Fig. 2: S-curve of bed material obtained from Sungai Perak.

Based on observation, the uniformity of bed material for Sungai Perak was slightly higher on October 2015 compared to the data on June 2015. The gradation of bed materials was also higher for bed material collected on October 2015. The average median size indicated that bed material size was bigger on October 2015 compare to the data collection on June 2015. This is because on the June data were collected during dry season where river becomes shallow and river flow was also slower. It can also cause the sediment to become smaller, poorly graded and non-uniform when compared data obtained on October 2015.

\subsection{Sungai Kurau Sediment Size Distributions}

Sungai Kurau is a small river with a width in the ranges of 9 to 11 meters. This river carries the much smaller sediment load compare to Sungai Perak. The size distributions of sediment are simplified in Table 4 and Table 5. The $\mathrm{d}_{50}$ of bed loads obtained in Sungai Kurau were in the range of 0.72 and $1.27 \mathrm{~mm}$. The result showed that Sungai Kurau was carried mostly very coarse sand. The graph of sieve analysis for bed load is plotted in Figure 3. The median size of bed loads was in the range of 0.8 to $1.8 \mathrm{~mm}$.

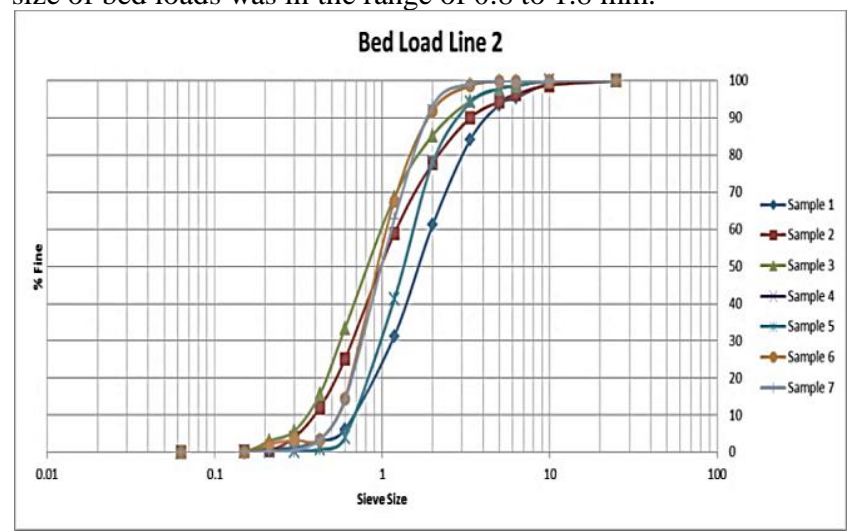

Fig. 3: S-curve of bed load obtained from Sungai Kurau.

The uniformity of sediment in this river can be classified as uniform when the result is less than 3. Only result the SKRU3/09/15 sample is more than 3 which can be classified as non-uniform sediment. The gradation of sediment mixture can be categorized as poorly graded mixture with the value of sediment gradation more than 1.4. The lowest value of gradation is 1.46 and the highest value is 2.32 which indicates that sediment is poorly graded. The detailed size of sediment, uniformity and gradation of bed load as shown in Table 5 .

Based on the analysis in Table 6 , the median sizes of this river ranges from $1.08 \mathrm{~mm}$ to $2.0 \mathrm{~mm}$ which are can considered as very coarse sand. The uniformity of bed material of this river was in the range of 2.40 to 4.66 . The overall average of sediment uniformity was 3.28. The uniformity of this bed material can classified as non-uniform sediment mixture. The detail bed material sediment size distributions are shown in the Table 6. Further, the typical of particles size distribution of bed materials obtained from Sungai Kurau as shown in Figure 4.

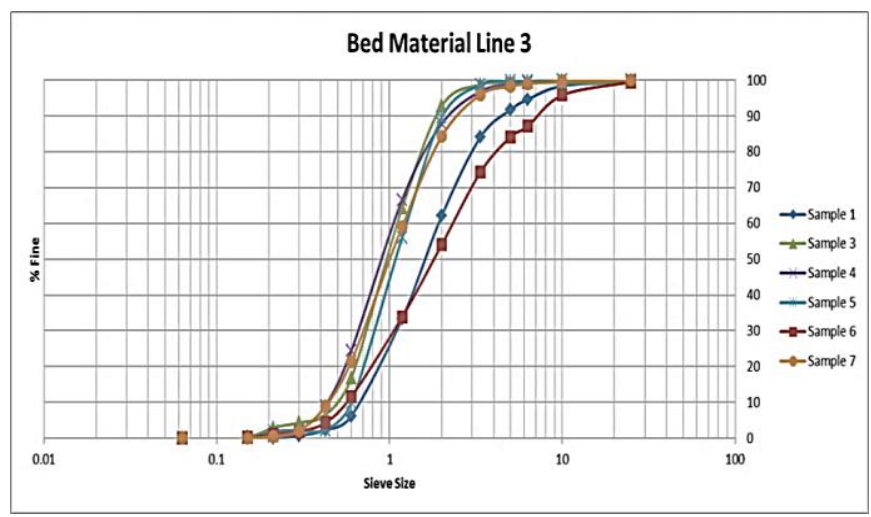

Fig. 4: S-curve of bed material obtained from Sungai Kurau.

\section{Conclusions}

Based on the results, the bed loads of the two rivers are nearly uniform mixture. However, bed material for these two rivers is poorly graded sand. For gradation of sediment, both rivers carried the poor graded sediment with the average value of coefficient is more than 1.4. The results proved that the Malaysia rivers are mostly carried the uniform bed load as founded by $[3,13]$. Non-uniform sediments usually can lower scour depths than that in uniform sediments[14].[13] added that when the value of uniformity is high, it indicates that the high volume of fine sediment occurs in that sediment mixture. The most suitable site for sand mining is Sungai Perak which carries sediment load about 3560 ton/day. The high sediment capacity enables the supply of sand to construction industry. The median size of bed loads are mostly range from 0.62 to 2.94 $\mathrm{mm}$ can be classified as sand and fine gravel material which can be used for construction material.

\section{Acknowledgement}

The authors would like to acknowledge the Ministry of Education Malaysia for providing USM RUI Grant entitled Exploratory Study on the Sustainable Sand Removal Capacity on Sand Mining Activities [1001/PPKA/814218].

\section{References}

[1] Dey S. Fluvial Hydrodynamics Hydrodynamic and Sediment Transport Phenomena: Springer; 2014. 8821- p

[2] Wu B, Molinas A, Julien PY. Bed-Material Load Computations for Nonuniform Sediments. Journal of Hydraulic Engineering. 2004;130[October]:1002-12.

[3] Sinnakaudan SK, Ab. Ghani A, Ahmad MS, Zakaria NA. Multiple Linear Regression Model for Total Bed Material Load Prediction. Journal of Hydraulic Engineering. 2006;132[5]:521-8.

[4] van Rijn L. Simple General Formulae for Sand Transport in Rivers, Estuaries and Coastal Waters. 1993.

[5] Julien PY. River Mechanics. Cambridge: Cambridge University Press; 2002

[6] Berita Harian O. Banjir di Perak terus buruk, 6,000 dipindahkan. 2014.

[7] Ab. Ghani A, Zakaria NA, Abdullah R, Chang CK, Sinnakaudan SK, Mohd Sidek L. Guidelines for Field Data Collection and Analysis of River Sediment. 2003.

[8] Rickly Hydrological C. Bedload Samplers. 2009.

[9] Ariffin J. Development of Sediment Transport Models for Rivers in Malaysia Using Regression Analysis and Artificial Neural Network: Universiti Sains Malaysia; 2004.

[10] Chang CK, Ab. Ghani A. Sediment Transport in Kulim River, Kedah, Malaysia. In: Ginsberg SS, editor.: InTech; 2010. p. 175-

[11] Wren DG, Barkdoll BD, Kuhnle Ra, Derrow RW. Field Techniques for Suspended-Sediment Measurement. Journal of Hydraulic Engineering. 2000;126[February]:97-104.

[12] Rickly Hydrological C. Van Veen Grab Sampler. 2009.

[13] Chang CK. Sediment Transport in Sungai Kulim, Kedah: Universiti Sains Malaysia; 2006

[14] Dey S, Sarkar A. Scour Downstream of an Apron Due to Submerged Horizontal Jets. Journal of Hydraulic Engineering. 2006;132 [3]:246-57. 